\title{
The Influence of Organic Fertilizers on the Abundance of Soil Microorganism Communities, Agrochemical Indicators, and Yield in East Lithuanian Light Soils
}

\author{
Diana Sivojiene $^{1, *}$, Audrius Kacergius ${ }^{1}\left(\mathbb{D}\right.$, Eugenija Baksiene ${ }^{1}$, Aiste Maseviciene ${ }^{2}$ and Lina Zickiene ${ }^{2}$ \\ 1 Lithuanian Research Centre for Agriculture and Forestry, Vokè Branch of Institute of Agriculture, Žalioji Sq. 2, \\ LT-02232 Vilnius, Lithuania; audrius.kacergius@lammc.lt (A.K.); eugenija.baksiene@lammc.lt (E.B.) \\ 2 Agrochemical Research Laboratory of Institute of Agriculture, Lithuanian Research Centre for Agriculture \\ and Forestry, Savanoriu Av. 287, LT-50127 Kaunas, Lithuania; aiste.maseviciene@lammc.lt (A.M.); \\ lina.zickiene@lammc.lt (L.Z.) \\ * Correspondence: diana.sivojiene@lammc.lt
}

Citation: Sivojiene, D.; Kacergius, A.; Baksiene, E.; Maseviciene, A.; Zickiene, L. The Influence of Organic Fertilizers on the Abundance of Soil Microorganism Communities, Agrochemical Indicators, and Yield in East Lithuanian Light Soils. Plants 2021, 10, 2648. https://doi.org/ $10.3390 /$ plants 10122648

\section{Academic Editors: Giedrè}

Samuolienè, Neringa Rasiukeviciute, Lina Šernaitè and Darius Kviklys

Received: 21 October 2021

Accepted: 29 November 2021

Published: 2 December 2021

Publisher's Note: MDPI stays neutral with regard to jurisdictional claims in published maps and institutional affiliations.

Copyright: (c) 2021 by the authors. Licensee MDPI, Basel, Switzerland. This article is an open access article distributed under the terms and conditions of the Creative Commons Attribution (CC BY) license (https:// creativecommons.org/licenses/by/ $4.0 /)$.

\begin{abstract}
Soil microorganisms are one of the main indicators used for assessing the stability of the soil ecosystem, the metabolism in the soil, and its fertility. The most important are the active soil microorganisms and the influence of the fertilizer applied to the soil on the abundance of these microorganisms. We aimed to investigate how the applied organic fertilizers affect the most active soil microorganisms, which determine the soil fertility and stability. Fungi, yeast-like fungi abundance, and abundance of three physiological groups of bacteria were analyzed: non-symbiotic diazotrophic, organotrophic, and mineral nitrogen assimilating. This study is valuable because relatively few similar studies have been performed on infertile Lithuanian soils. The first results of a long-term study were obtained. The results show the effect of fertilizers on trends in the changes of microorganism community diversity; however, more analysis is needed to assess the impact of organic fertilizers on the most active soil microorganisms. Therefore, the investigation was continued. The results of the 2020 quantitative analysis of culturable soil microorganisms show that the highest abundance of organotrophic and non-symbiotic diazotrophic bacteria were recorded during the summer season. Meanwhile, the abundance of bacteria assimilating mineral nitrogen and fungi was higher in autumn. Agrochemical parameters were determined the beginning of the experiment. The highest concentration of $\mathrm{N}_{\min }$ in the soil was determined after fertilizing the plants with the combination of granulated poultry manure $\left(\mathrm{N}_{170}\right)+$ biological substance Azotobacter spp. The yield of barley was calculated. It was found that the highest yield of spring barley in 2020 was obtained by fertilizing the experimental field with organic in combination with mineral fertilizers.
\end{abstract}

Keywords: physiological groups of soil microorganisms; fertilization; agroecosystems

\section{Introduction}

On a global scale, only a small part of the planet's land area is suitable for agriculture; therefore, it is very important to keep the soil fertile [1]. Soil microorganisms play an important role in the process of maintaining soil fertility; they are the most important participants in the transformation (change) of various organic and mineral substances, which determine the yield of plants [2,3].

Intensive fertilization of the soil with mineral fertilizers has a negative effect on the soil biota, and the diversity of microorganism species decreases, which promotes the appearance of niches for the establishment of pathogenic organisms. With the right farming strategy, soil microorganisms enrich and supplement plants with a variety of necessary and available compounds. Without good farming conditions and intensification of agricultural activities, the amount and activity of microorganisms decreases significantly, resulting in poor plants and crop yields. Therefore, with the intensification of agricultural activities, 
research on the diversity and activity of soil microorganisms is becoming especially important. Research has already shown that greater diversity of microorganism communities has a decisive impact on soil quality [4-9].

Fertilization with organic fertilizers increases the mass and diversity of the soil microbiota, which is very important for the decomposition of organic matter and plant nutrition [10,11]. Litter cattle manure enriches soil with organic carbon, increasing its fertility, and binds soil organic aggregates, thus increasing their stability and reducing the degradation of organic matter [12,13]. Recently, the use of granular organic fertilizers, made not only from cattle but also from poultry litter, which is rich in nutrients available to plants, and free of weed seeds and pathogens, is becoming more widespread [14-17]. The use of animal manure for fertilization is recommended, but its effects on soil microorganism communities have not been definitively elucidated. Some recent studies suggest that pig and chicken manure significantly increases the abundance of soil bacteria by correlating with an increase in total soil nitrogen. Meanwhile, composted pig manure reduced the amount of some organotrophic bacteria [18]. Some research shows the advantage of granular organic fertilizers over ordinary manure [19]. However, single fragmentary studies are not enough. Granular fertilizers can also be produced from sewage sludge, thus solving the problem of using this waste [20].

The specific biocenosis of microorganisms depends primarily on the agrochemical properties of soil. Another important factor is the cultivated agricultural crops, their change, and the use of fertilizers and other chemicals [21-23]. The amount of mineral nitrogen $\left(\mathrm{N}-\mathrm{NH}_{4}\right.$ and $\left.\mathrm{N}-\mathrm{NO}_{3}\right)$ in the soil is very important for plant nutrition, which is constantly changing due to the activity of microorganisms, fertilization technologies, precipitation, ambient temperature, granulometric composition, organic matter content, soil moisture, and other factors [24-27]. The amount of nitrogen in the soil not only determines the yield and quality of agricultural crops, but its excess has a negative impact on the environment. Once in the soil, nitrogen is constantly transformed, and its most dangerous form is nitrates [27-29]. The nitrate concentration in the soil can be increased by mineralization processes of organic matter that are too fast, excessive amounts of fertilizers, high environmental and soil temperatures, and slow infiltration properties of the topsoil [25,30,31]. In the presence of excess water (precipitation), nitrogen is easily leached from the soil, mainly in the form of nitrates $\left(\mathrm{N}-\mathrm{NO}_{3}\right)(90-98 \%)$ [28]. In addition, the Nitrates Directive (91/676EEC) [32] obliges and promotes the protection of European Union waters against nitrate pollution. Therefore, it is very important to know how the amounts of mineral nitrogen in the soil change, not only due to different organic fertilizers, but also how environmental factors can affect it, with the highest probability of nitrogen leaching.

Studies of soil microorganisms, due to their high abundance in a small volume of soil, are quite difficult but very important in terms of ecosystem stability, soil metabolism, and fertility $[8,33,34]$. The most active soil microorganisms are the most important in this case, as well as the influence of fertilizers applied to the soil on these microorganisms.

Studies shows that low rates of mineral fertilizers have a positive effect on plant productivity and soil agrochemical and microbiological properties. Mineral fertilizers stimulate the growth of ammonifying and nitrifying microorganisms, as well as the proliferation of spore-forming bacteria and stimulates the mineralization of crop residues [35-37]. However, the use of mineral fertilizers to increase fertility leads to complete soil degradation. Long-term scientific research by Gautam and co-authors has shown a clear advantage of organic over mineral fertilization [38].

Scientists use a variety of methods to determine the composition, diversity, and abundance of soil microorganism communities. The estimates of the abundance of microorganisms performed by the method of inoculation and cultivation allow the typical presence of active microorganism populations in the soil to be revealed, which, in fact, determine the condition and productivity of the soil $[39,40]$. 
This long-term experiment investigates for the first time the effects of new rates of granular poultry and cattle manure fertilizers and their combinations with bioadditives on soil microbiological activity, ecological condition, soil sustainability, and crop productivity. The initial microbiological studies discussed in this article are one of the contributions to the overall long-term study. Therefore, the aim of these studies was to determine the influence of different organic fertilizers and their combinations with biological additives on soil microbiota and the mineral nitrogen concentration in soil, as well as the spring barley yield.

\section{Results and Discussion}

\subsection{Abundance of Different Physiological Groups of Soil Microorganisms}

In order to evaluate the influence of fertilizers applied to the soil on the abundance of physiological groups of most active soil microorganisms, the obtained quantitative data were compared according to different fertilization options. Organic fertilizers were applied to the soil in the autumn of the first year of investigation in 2018 and mineral fertilizers were applied to the soil in 2020, before pre-sowing tillage (ploughing). The abundance and changes in the amount of different physiological groups of cultivable soil microorganisms in the plant vegetation period in 2020 were observed during the quantitative analysis (Figures 1-4).

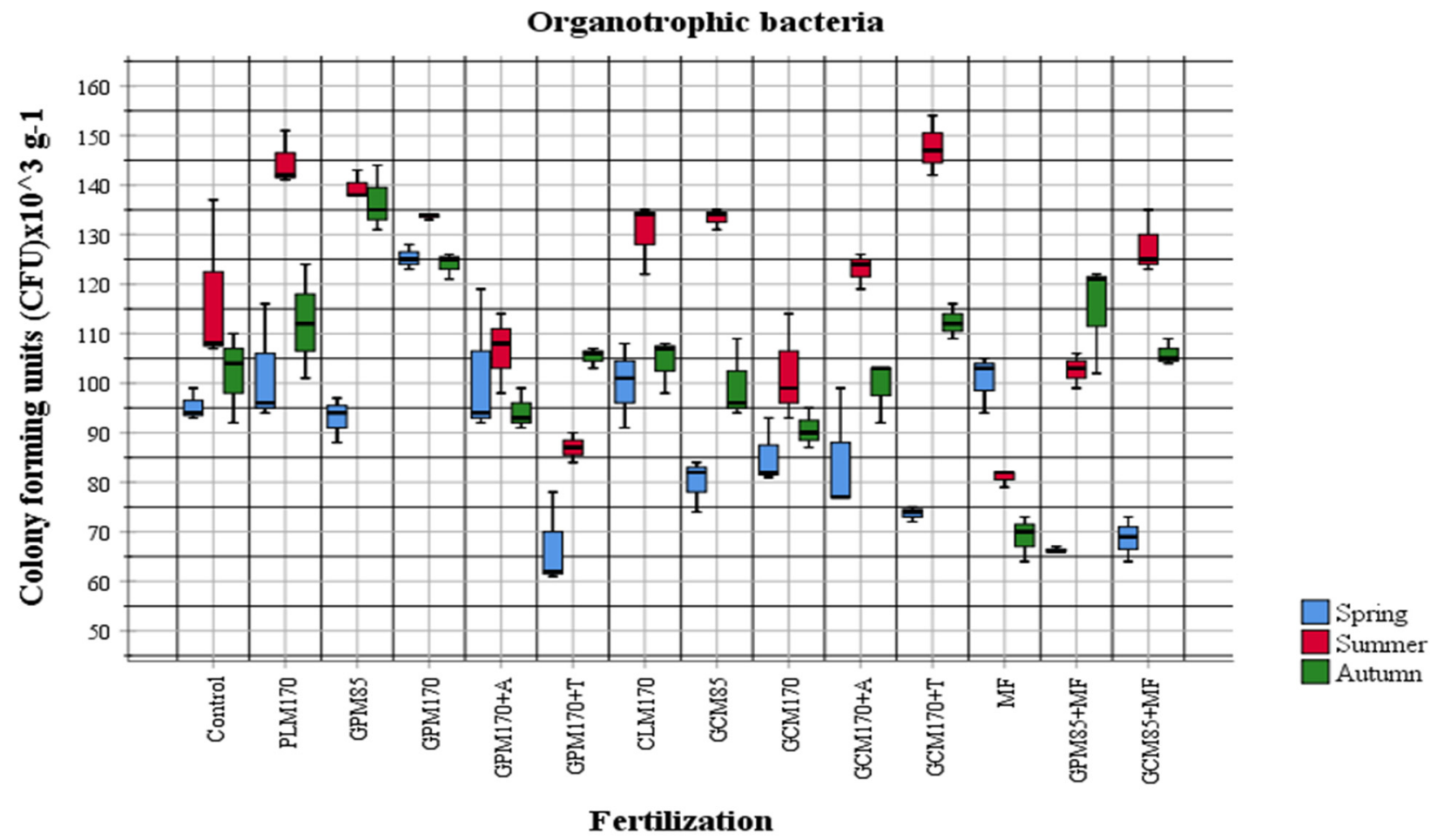

Figure 1. The abundance of organotrophic bacteria in $2020(p<0.05)$. 


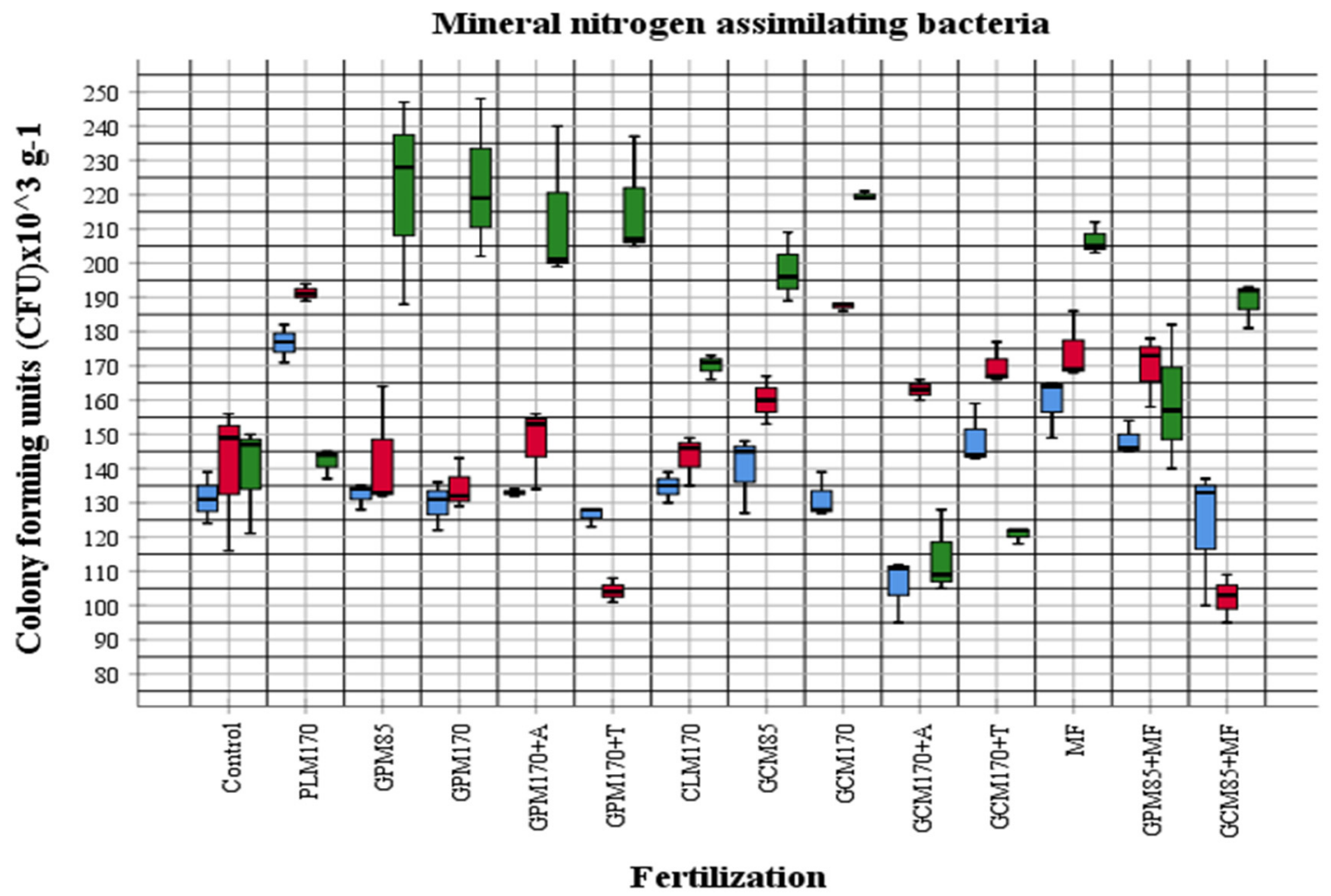

Figure 2. The abundance of mineral nitrogen-assimilating bacteria in $2020(p<0.05)$.

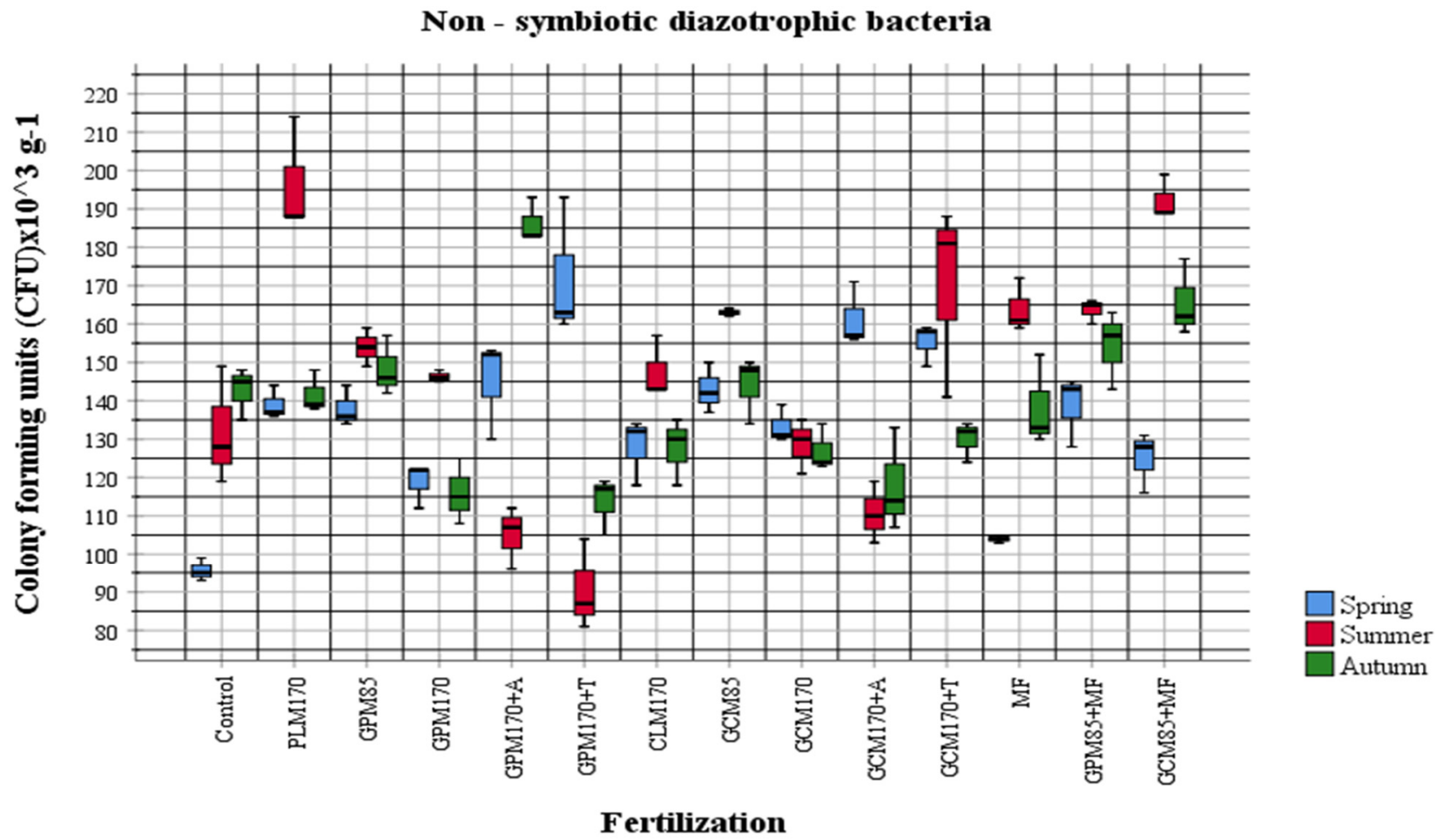

Figure 3. The abundance of non-symbiotic diazotrophic bacteria in $2020(p<0.05)$. 


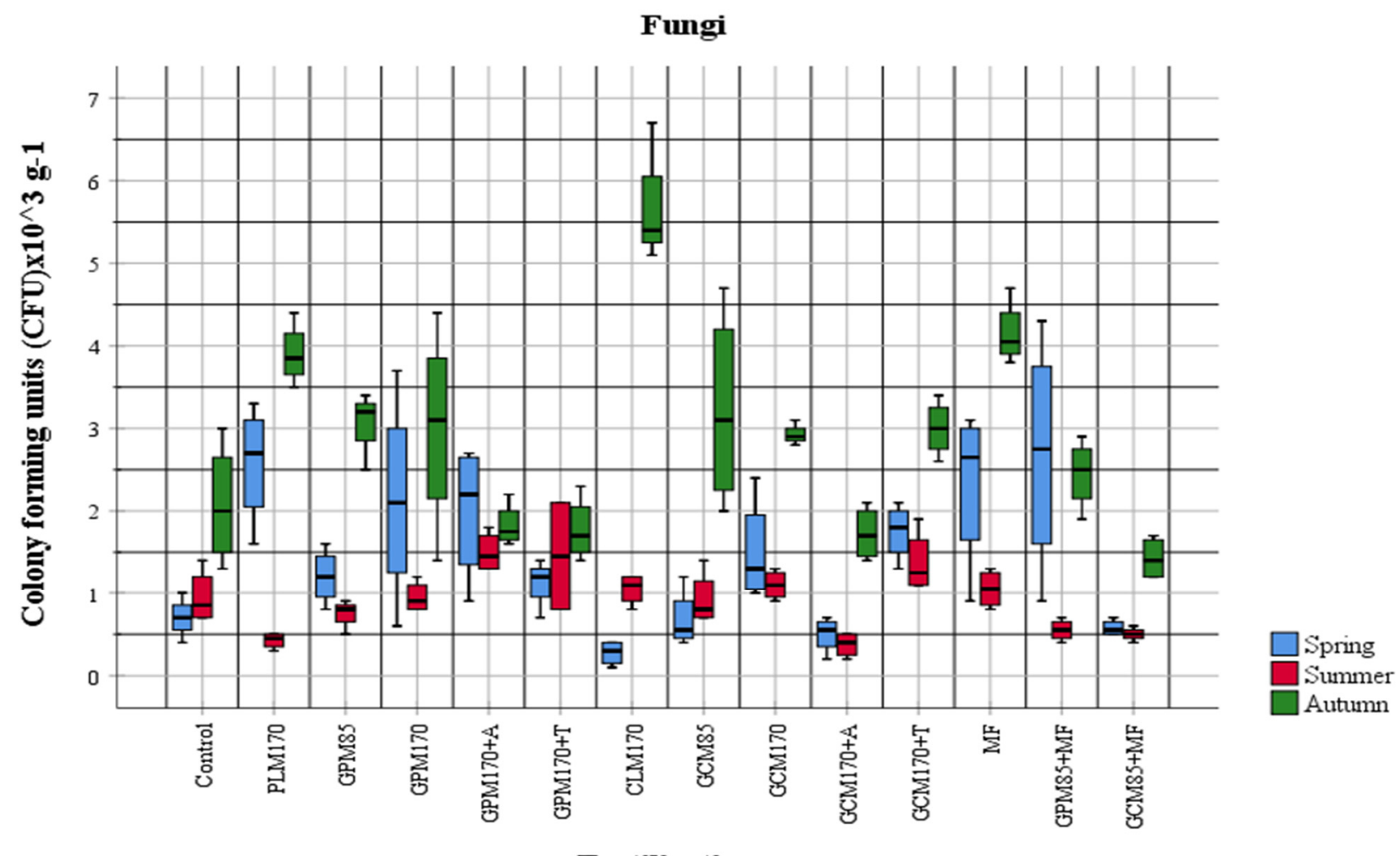

Fertilization

Figure 4. The abundance of fungi in $2020(p<0.05)$.

Studies by other authors have shown that fertilization with organic fertilizers initially increases the amount of ammonifiers (organotrophic bacteria), and later, especially at the end of the growing season, the amount of nitrifiers (mineral nitrogen-assimilating bacteria) increases [41]. Otherwise, if the abundance of nitrifiers is high in the spring, then nitrate depression is possible [42], while abundant mineral fertilization reduces the amount of nitrifiers.

The results of our investigations showed that in general, the abundance of organotrophic bacteria was highest in the summer period. Comparing the data of individual samples with the control, we see that the proportion of organotrophic bacteria was increased in all samples fertilized with manure, except for the samples with Trichoderma and mineral fertilizers. As the manure was added in the autumn of 2018, an increase in organotrophs was to be expected, but the environmental conditions for active manure processing were not favorable. In both 2019 and 2020, temperatures were high, but a lack of moisture was felt. In the spring of 2020, dried manure was observed during tillage. The abundance of diazotrophs was different in different areas compared to the control variant $\left(\mathrm{GPM}_{170}+\mathrm{A}, \mathrm{GPM}_{170}+\mathrm{T}\right)$ and showed a significant decrease during the summer (Figure 3). At that time, the amount of diazotrophs in the GPM + T sample was quite high in the spring (Figure 3). When manure is used for fertilization, an increase in organotrophs is usually observed first, followed by an increase in the abundance of nitrifiers, and an overall increase in soil activity is also observed [43,44]. Fertilization of manure also affects the taxonomic composition of microorganisms and increases the number of more active bacteria belonging to the taxonomic groups of Actinobacteria and Proteobacteria, which can grow in the nutrient medium [43-45]. In our studies, a significant increase in the abundance of nitrifiers was observed in samples fertilized with poultry manure in the autumn (Figure 1). The highest abundance of the fungal communities was also determined in autumn $\left(2.87 \pm 1.24 \times 10^{3} \mathrm{CFU} \mathrm{g}^{-1}\right)$. During the summer period, the representatives of this group were determined to be the lowest $\left(0.93 \pm 0.44 \times 10^{3} \mathrm{CFU} \mathrm{g}^{-1}\right)$. According to the microscopic and cultural features, predominant cultures strongly related to the 
genera Trichoderma, Paecilomyces, Cladosporium, Fusarium, Aureobasidium, Colletotrichum, Trichothecium, Penicillium, Saccharomyces, Mortierella, and Phiallophora were identified.

The data of our study demonstrate that mineral nitrogen-assimilating bacteria were most abundant in the MF-fertilized test field. Organotrophic bacteria were more abundant in the test field fertilized with granulated poultry manure, non-symbiotic diazotrophic bacteria in the granulated cattle manure combined with mineral fertilizers-fertilized field, and fungi in the MF-fertilized field.

\subsection{Investigations of Mineral Nitrogen in Soil}

Proper and timely use of organic fertilizers improves plant growth and development, and it is necessary for the formation of a humus layer in the soil. Lately, in addition to manure, i.e., organic fertilizers, granulated manure and other various liquid humic, biohumus, or plant extracts are increasingly used more frequently. Nitrogen is released from different types of organic fertilizers into plant uptake compounds with varying intensity; therefore, it is important to study the release of nutrients in the soil and their uptake.

Prior to the experiment, soil $\mathrm{pH}_{\mathrm{KCl}}$ was rather acidic (5.7-6.0), mobile phosphorus $\left(\mathrm{P}_{2} \mathrm{O}_{5}\right)$ was very high $\left(202-249 \mathrm{mg} \mathrm{kg}^{-1}\right)$, mobile potassium $\left(\mathrm{K}_{2} \mathrm{O}\right)$ was average (118-137 m kg $\left.{ }^{-1}\right)$, and mineral nitrogen $\left(\mathrm{N}_{\min }\right)$ and mineral sulphur $\left(\mathrm{S}_{\min }\right)$ 0-60 $\mathrm{cm}$ were average ( 8.11 and $2.69 \mathrm{mg} \mathrm{kg}^{-1}$ soil, respectively).

The concentrations of mineral nitrogen $\left(\mathrm{N}_{\min }\right)$ in the soil were mainly determined by fertilization of winter rye with organic fertilizers in autumn. Therefore, in the spring of 2019, higher concentrations of $N_{\text {min }}$ were accumulated in the soil (Table 1) compared to the previous autumn, when the above-mentioned indicator averaged $8.11 \mathrm{mg} \mathrm{kg}^{-1}$ before the establishment of the experiment, and only in the control and MF fields, the $\mathrm{N}_{\text {min }}$ concentration was lower. The evaluation of the effectiveness of different organic fertilizers demonstrated that in the 0-60 cm layer of soil, a higher content of these plant nutrients was found when fertilizing plants with both loose and granulated poultry manure fertilizers and combinations with biological substances than in fields fertilized with cattle manure. The concentrations of $\mathrm{N}_{\min }$ in the soil ranged from 12.50 to $15.68 \mathrm{mg} \mathrm{kg}^{-1}$ when fertilized with different rates and different forms of poultry manure, and with cattle manure from 7.98 to $11.57 \mathrm{mg} \mathrm{kg}^{-1}$. The highest $\left(15.68,13.96\right.$, and $\left.13.73 \mathrm{mg} \mathrm{kg}^{-1}\right) \mathrm{N}_{\min }$ concentrations were determined after the application of $\mathrm{GPM}_{170}+\mathrm{A}$ and $\mathrm{GPM}_{170}+\mathrm{T}$ and $\mathrm{GPM}_{170}$ or $\mathrm{GPM}_{85}+\mathrm{MF}$ to the soil. When fertilizing plants with granulated cattle manure, it was most effective in combination with a biological substance: $\mathrm{GCM}_{170}+\mathrm{A}$.

Table 1. Concentration of mineral nitrogen in the $0-60 \mathrm{~cm}$ soil layer in spring.

\begin{tabular}{|c|c|c|}
\hline \multirow{2}{*}{ Fertilization Variants } & \multicolumn{2}{|c|}{$\begin{array}{c}\text { Mineral Nitrogen }\left(\mathrm{N}_{\min }\right) \text { Concentration 0-60 cm Layer mg } \\
\mathrm{kg}^{-1} \pm \text { Standard Deviation (SD) }\end{array}$} \\
\hline & 2019 Spring & 2020 Spring \\
\hline $\mathrm{C}$ & $6.92 \pm 0.41$ & $1.29 \pm 0.33$ \\
\hline $\mathrm{MF}$ & $6.71 \pm 1.26$ & $1.60 \pm 0.38$ \\
\hline $\mathrm{PLM}_{170}$ & $13.13 \pm 1.13$ & $1.78 \pm 0.40$ \\
\hline $\mathrm{GPM}_{85}$ & $12.50 \pm 0.46$ & $1.64 \pm 0.27$ \\
\hline $\mathrm{GPM}_{170}$ & $13.73 \pm 1.69$ & $2.09 \pm 0.47$ \\
\hline $\mathrm{GPM}_{170}+\mathrm{A}$ & $15.68 \pm 0.56$ & $2.31 \pm 0.40$ \\
\hline $\mathrm{GPM}_{170}+\mathrm{T}$ & $13.96 \pm 1.57$ & $1.80 \pm 0.26$ \\
\hline $\mathrm{CLM}_{170}$ & $7.98 \pm 1.29$ & $1.90 \pm 0.30$ \\
\hline $\mathrm{GCM}_{85}$ & $7.66 \pm 0.11$ & $1.61 \pm 0.39$ \\
\hline $\mathrm{GCM}_{170}$ & $9.13 \pm 1.53$ & $1.88 \pm 0.42$ \\
\hline $\mathrm{GCM}_{170}+\mathrm{A}$ & $11.57 \pm 2.74$ & $1.99 \pm 0.42$ \\
\hline $\mathrm{GCM}_{170}+\mathrm{T}$ & $9.95 \pm 1.71$ & $1.77 \pm 0.26$ \\
\hline $\mathrm{GPM}_{85}+\mathrm{MF}$ & $13.42 \pm 0.78$ & $2.02 \pm 0.29$ \\
\hline $\mathrm{GCM}_{85}+\mathrm{MF}$ & $9.51 \pm 0.37$ & $1.84 \pm 0.25$ \\
\hline
\end{tabular}


In the spring of 2020 , the $\mathrm{N}_{\text {min }}$ concentration in the soil was significantly less than in 2019. These low $\mathrm{N}_{\text {min }}$ concentrations were largely due to the lighter particle size distribution of the soil and the warmer than usual meteorological conditions during the winter-spring period, when in the absence of freezing, soil and rain $\mathrm{N}_{\text {min }}$ leaches from the top layers to the deeper layer, and eventually to the groundwaters. These trends have been confirmed by other researchers. Swedish researchers claim that nitrogen leaching is increased by warm winters, higher rainfall, lighter soils, and higher organic matter [46]. According to research by Rutkowska and Fotyma (2011) [47], the amount of mineral nitrogen in the soil is highly dependent on the granulometric composition of the soil. Žičkienè (2016) [48] also found that the concentration of mineral nitrogen in the 0-60 cm soil layer in spring depended mostly on the average precipitation and average air temperature (November-March) in soils with a light granulometric composition. Therefore, due to the prevailing soil moisture regime in the country, higher precipitation during the winter is likely to affect nitrate leaching into deeper soil layers, resulting in the low $\mathrm{N}_{\text {min }}$ levels in the soil in the spring of 2020. In addition, the effectiveness on the $\mathrm{N}_{\min }$ concentration of both litter and granulated poultry and cattle manure fertilizers applied two years ago was not determined either. Irrespective of pre-sowing fertilization with organic fertilizers, the content of mineral nitrogen in the 0-60 cm soil layer was very low and varied from $1.29 \mathrm{mg} \mathrm{kg}^{-1}$ in the control plot, and from 1.60 to $2.31 \mathrm{mg} \mathrm{kg}^{-1}$ in the fertilized plot. Slightly higher $\mathrm{N}_{\text {min }}$ concentrations were determined only when fertilizing plants with $\mathrm{GPM}_{170}, \mathrm{GPM}_{170}+\mathrm{A}$, and $\mathrm{GPM}_{85}+\mathrm{MF}$. According to various authors, the use of composted or ordinary manure for fertilization prevents the active leaching of nitrogen from the soil, especially sandy loam [49-51]. In general, the use of biochar not only increases the nitrogen content in the soil, and initiates the activity of microorganisms, but also prevents nitrogen leaching [52].

The evaluation of the efficiency of biological substances for the mentioned indicator demonstrated that in 2020 of the investigation, only the biological substance with the nitrogen-fixing bacterium Azotobacter spp. (No 1) showed a tendency to increase the concentration of $\mathrm{N}_{\min }$ in the soil (Table 1). It worked effectively when used in combination with both $\mathrm{GPM}_{170}$ and $\mathrm{GCM}_{170}$. The effect of the biological substance containing the fungus Trichoderma spp. (No 2) was less regular, and in 2020, when used in combination with both $\mathrm{GPM}_{170}$ and $\mathrm{GCM}_{170}$, less $\mathrm{N}_{\text {min }}$ was found in the soil than when fertilizing with granulated poultry or cattle manure at the rate of $170 \mathrm{~kg} \mathrm{ha}^{-1}$.

Summarizing the results of the two-year study, it can be seen that the concentration of mineral nitrogen depends not only on the fertilization with organic fertilizers, but also on the meteorological conditions in the winter-spring period. The effectiveness of organic fertilizers compared to unfertilized plants became apparent only in the first year of the investigation after their application. The evaluation of the efficiency of the biological substances showed that the biological substance with the nitrogen-fixing bacterium Azotobacter spp. (No 1) tended to increase the $\mathrm{N}_{\min }$ concentration in soil when used in combination with both $\mathrm{GPM}_{170}$ and $\mathrm{GCM}_{170}$. According to Schlegel and coauthors, organic manure contains many macro and trace elements and organic matter that improve the chemical and physical properties of the soil and the microbial biomass, and at the same time increase crop yields [53]. It has also been found that the use of chicken manure fertilizers can maintain a stable amount of nutrients in the soil and reduce the release of mineral fertilizers into the environment [54].

\subsection{Spring Barley Yield}

The evaluation of the 2020 barley yield results demonstrated that the highest yield supplement was obtained by using GPM $_{85}+$ MF for soil fertilization, as well as GCM G5 $_{85}$ $+\mathrm{MF}$ and MF. The higher yield is due to the fact that mineral fertilizers were applied to the soil in 2020, before pre-sowing cultivation (ploughing), and organic fertilizers in the autumn of the first year of the investigation (2018). Similarly, a higher straw yield and a maximum 1000-grain weight from the correspondingly fertilized soil was observed. 
The 2020 barley yield results are presented in Table 2. Several researchers have also found that mineral fertilizers increase crop yields more than granular organic (OGF) or granular organic fertilizers with mineral additives (OMF). Nutrients from OGF and OMF are released at a slower rate and can be regarded as a delayed release [16,55]. Therefore, it is likely that slower nitrogen release allows nutrients to be retained in the soil for longer, so plants use them throughout the growing season, which can also have a positive effect on their yield. Additionally, Correa and co-authors observed that the use of organo-mineral fertilizers with inhibitors increased the yield of corn and wheat crops compared to organic fertilizers [56].

Table 2. Spring barley harvest (2020).

\begin{tabular}{|c|c|c|c|c|}
\hline Fertilization Variants & $\begin{array}{c}\text { Clean, } 15 \% \text { Humidity } \\
\text { Grain Yield t/ha } \pm \\
\text { Standard Deviation } \\
\text { (SD) }\end{array}$ & Grain-Straw Ratio & $\begin{array}{l}\text { Straw Yield } \mathrm{t} / \mathrm{ha} \pm \\
\text { Standard Deviation } \\
\text { (SD) }\end{array}$ & $\begin{array}{l}1000 \text { Grain Weight } g \pm \\
\text { Standard Deviation } \\
\text { (SD) }\end{array}$ \\
\hline $\mathrm{C}$ & $1.20 \pm 0.04$ & $1: 1.01$ & $1.21 \pm 0.13$ & $38.2 \pm 1.68$ \\
\hline MF & $2.72 \pm 0.20$ & 1:0.98 & $2.67 \pm 0.47$ & $46.4 \pm 1.34$ \\
\hline $\mathrm{PLM}_{170}$ & $1.49 \pm 0.30$ & $1: 0.90$ & $1.33 \pm 0.19$ & $41.0 \pm 0.38$ \\
\hline $\mathrm{GPM}_{85}$ & $1.30 \pm 0.35$ & 1:0.99 & $1.30 \pm 0.40$ & $38.1 \pm 1.98$ \\
\hline $\mathrm{GPM}_{170}$ & $1.26 \pm 0.11$ & 1:0.98 & $1.23 \pm 0.12$ & $39.7 \pm 1.61$ \\
\hline $\mathrm{GPM}_{170}+\mathrm{A}$ & $1.22 \pm 0.13$ & 1:0.95 & $1.15 \pm 0.09$ & $40.5 \pm 1.41$ \\
\hline $\mathrm{GPM}_{170}+\mathrm{T}$ & $1.31 \pm 0.14$ & 1:0.95 & $1.24 \pm 0.12$ & $39.3 \pm 0.52$ \\
\hline $\mathrm{CLM}_{170}$ & $1.48 \pm 0.08$ & 1:0.89 & $1.31 \pm 0.11$ & $39.7 \pm 2.06$ \\
\hline $\mathrm{GCM}_{85}$ & $1.10 \pm 0.04$ & $1: 1.03$ & $1.13 \pm 0.06$ & $38.5 \pm 0.86$ \\
\hline $\mathrm{GCM}_{170}$ & $1.21 \pm 0.04$ & $1: 1.06$ & $1.28 \pm 0.16$ & $37.7 \pm 2.43$ \\
\hline $\mathrm{GCM}_{170}+\mathrm{A}$ & $1.14 \pm 0.02$ & $1: 1.04$ & $1.18 \pm 0.07$ & $37.9 \pm 2.12$ \\
\hline $\mathrm{GCM}_{170}+\mathrm{T}$ & $1.08 \pm 0.03$ & $1: 1.03$ & $1.12 \pm 0.05$ & $37.7 \pm 1.48$ \\
\hline $\mathrm{GPM}_{85}+\mathrm{MF}$ & $3.15 \pm 0.02$ & 1:0.97 & $3.04 \pm 0.32$ & $46.7 \pm 0.94$ \\
\hline $\mathrm{GCM}_{85}+\mathrm{MF}$ & $3.00 \pm 0.02$ & 1:0.99 & $2.96 \pm 0.41$ & $45.9 \pm 0.58$ \\
\hline
\end{tabular}

\section{Materials and Methods}

\subsection{Experimental Treatments and Design}

Quantitative research of soil microorganisms was performed in the Lithuanian Research Centre for Agriculture and Forestry in the laboratory of the Voke branch of Institute of Agriculture. The soil samples were taken from the field of a long-term experiment started in the autumn of 2018. The soil of the experimental site is basic illimerised soil (according to FAO, the soil of the experimental site is Sandy Loam Haplic Luvisol). The total area of the experimental field is $24 \mathrm{~m}^{2}(6 \times 4 \mathrm{~m})$, and the accounting area is $15 \mathrm{~m}^{2}$ $(5 \times 3 \mathrm{~m})$. The field layout was randomized, with four replications.

The two most used types of organic fertilizers for agricultural crops were selected for the investigation litter and granulated (poultry and cattle) manure. These fertilizers differ in the amount of nutrients (concentration) and the intensity of nutrient release. Organic and mineral fertilizers were used in the field experiment: poultry litter manure (PLM), peat cattle litter manure (CLM), granulated poultry manure (GPM), granulated cattle manure (GCM), and mineral fertilizers (MFs) (ammonium nitrate $(34.4 \% \mathrm{~N})$, granulated superphosphate $\left(19.0 \% \mathrm{P}_{2} \mathrm{O}_{5} ; 13.0 \% \mathrm{~S}\right)$, and potassium chloride $\left.\left(60.0 \% \mathrm{~K}_{2} \mathrm{O}\right)\right)$. The abbreviations are explained in Table 3.

Organic fertilizers were applied to the soil in the autumn of the first year of the investigation (2018), for winter rye, and in the third year, in autumn 2020, before growing potatoes in 2021. The rate of organic fertilizer was calculated based on $170 \mathrm{~kg} \mathrm{ha}^{-1}$ of nitrogen active substance. Mineral fertilizers for winter rye were applied after the regeneration of plant vegetation, and for the remaining crop rotation plants, before presowing cultivation (ploughing). Winter rye and potatoes were fertilized at the $\mathrm{N}_{90} \mathrm{P}_{60} \mathrm{~K}_{90}$ mineral fertilizer rate, and spring barley and spring wheat at $\mathrm{N}_{60} \mathrm{P}_{60} \mathrm{~K}_{60}$. 
Table 3. Explanation of abbreviations.

\begin{tabular}{|c|c|}
\hline Abbreviation & Explanation \\
\hline $\mathrm{C}$ & control (without fertilizer $-\mathrm{N}_{0} \mathrm{P}_{0} \mathrm{P}_{0}$ ) \\
\hline MF & mineral fertilizers $\left(\mathrm{N}_{90 / 60}{ }^{*}\right)$ \\
\hline $\mathrm{PLM}_{170}$ & poultry litter manure $\left(\mathrm{N}_{170}\right)$ \\
\hline $\mathrm{GPM}_{85}$ & granulated poultry manure $\left(\mathrm{N}_{85}\right)$ \\
\hline $\mathrm{GPM}_{170}$ & granulated poultry manure $\left(\mathrm{N}_{170}\right)$ \\
\hline $\mathrm{GPM}_{170}+\mathrm{A}$ & $\begin{array}{l}\text { granulated poultry manure }\left(\mathrm{N}_{170}\right)+\text { biological substance No } 1 \\
\text { (Azotobacter spp.) }\end{array}$ \\
\hline $\mathrm{GPM}_{170}+\mathrm{T}$ & $\begin{array}{l}\text { granulated poultry manure }\left(\mathrm{N}_{170}\right)+\text { biological substance No } 2 \\
\text { (Trichoderma spp.) }\end{array}$ \\
\hline $\mathrm{CLM}_{170}$ & peat cattle litter $\left(\mathrm{N}_{170}\right)$ \\
\hline $\mathrm{GCM}_{85}$ & granulated cattle manure $\left(\mathrm{N}_{85}\right)$ \\
\hline $\mathrm{GCM}_{170}$ & granulated cattle manure $\left(\mathrm{N}_{170}\right)$ \\
\hline $\mathrm{GCM}_{170}+\mathrm{A}$ & $\begin{array}{l}\text { granulated cattle manure }\left(\mathrm{N}_{170}\right)+\text { biological substance No. } 1 \\
\text { (Azotobacter spp.) }\end{array}$ \\
\hline $\mathrm{GCM}_{170}+\mathrm{T}$ & $\begin{array}{l}\text { granulated cattle manure }\left(\mathrm{N}_{170}\right)+\text { biological substance No. } 2 \\
\text { (Trichoderma spp.) }\end{array}$ \\
\hline $\mathrm{GPM}_{85}+\mathrm{MF}$ & granulated poultry manure $\left(\mathrm{N}_{85}\right)+$ mineral fertilizers $\left(\mathrm{N}_{90 / 60} *\right)$ \\
\hline $\mathrm{GCM}_{85}+\mathrm{MF}$ & granulated cattle manure $\left(\mathrm{N}_{85}\right)+$ mineral fertilizers $\left(\mathrm{N}_{90 / 60}{ }^{*}\right)$ \\
\hline
\end{tabular}

A non-commercial biological additive was used in the experiment: nitrogen-fixing bacteria Azotobacter spp. (No 1) - A (a mixture of two cultures: A. chroococcum and A. vinelandii together with the residues of the culture medium), microelements (manganese, iron, copper, molybdenum, zinc, and cobalt), and vitamins (B1, B3, B6), no more than $0.02 \%$; biological substance containing the fungi Trichoderma spp. (No 2), T. enriched with phytohormones (a mixture of three cultures: T. harzianum, T. tomentosum, and T. viride). Biological substances were sprayed annually in spring for all crops on the soil prior to sowing or until the plants completely covered the soil surface, except for winter rye.

The experiment was performed in the following crop rotation order: winter rye (2018/2019), spring barley (2020), potatoes (2021), spring wheat (2022), and winter rye $(2023 / 2024)$. The preceding crop was buckwheat.

\subsection{Soil Sampling and Microbial Count}

The prevalence of different physiological groups of cultivable soil microorganisms was determined in soil samples of natural moisture. The soil samples were taken from a $10-20 \mathrm{~cm}$ deep arable layer from the four replicates of the relevant test fields and a pooled sample was formed from four replicates of each sample. For the quantitative analysis of microorganisms, samples were taken three times during the vegetation period (spring, summer, and autumn) and performed using the plate count technique by inoculating the diluted soil suspension on appropriate agar media [57]: for micromycetes and yeasts, Sabouraud agar with chloramphenicol (200 ppm) (Liofilchem, Italy); for organotrophic bacteria, meat peptone nutrient agar (Liofilchem, Italy); for mineral nitrogen-assimilating bacteria, starch-ammonium agar [58]; and for atmospheric nitrogen-fixing bacteria (diazotrophs), Ashby's mannitol agar [59]. Serial dilutions were prepared to obtain $10^{-2}$ and $10^{-3}$ soil suspension, and then $0.1 \mathrm{~mL}$ of each dilution were spread on certain nutrient agar in Petri plates with five replicates. Petri dishes with inoculated samples were cultivated at $25^{\circ} \mathrm{C}$ in the dark for 7-12 days. The content of microorganisms in colony-forming units (CFU) per $1 \mathrm{~g}$ of dry soil was calculated according to the Carter and Gregorich methodology [60]. Fungal colonies on agar were examined microscopically and predominant genera according to handbooks and manuals were identified [61-66].

\subsection{Soil Agrochemical Analysis}

The analyses of the soil agrochemical properties were performed before and after the test installation the investigation. 
Their methods, depths, and time are presented in Table 4. After collection, soil samples were air-dried or oven-dried at a temperature no higher than $40^{\circ} \mathrm{C}$. Then, soil samples were milled, passed through a $2 \mathrm{~mm}$ sieve, and stored in an airtight room in a soil sample storage rack.

Table 4. Methods for analysis of the soil agrochemical properties.

\begin{tabular}{|c|c|c|c|}
\hline Indicators & Investigation Method & $\begin{array}{l}\text { Sampling Time and Frequency, } \\
\text { Depth } \mathrm{cm}\end{array}$ & Sources \\
\hline Mobile phosphorus $\left(\mathrm{P}_{2} \mathrm{O}_{5}\right)$ & $\begin{array}{c}1 \mathrm{M} \mathrm{KCl} \text { extraction by } \\
\text { potentiometric method } \\
\text { By Egner-Riehm-Domingo } \\
\text { (A-L) method in a buffer } \\
\text { solution (pH 3.7) extraction } \\
\text { (spectrophotometer) }\end{array}$ & $\begin{array}{l}\text { Samples ( } \mathrm{pH} \text {, mobile } \mathrm{P}_{2} \mathrm{O}_{5} \text {, mobile } \\
\mathrm{K}_{2} \mathrm{O} \text { ) are taken in the fall before the } \\
\text { experiment is set up (2018) and after } \\
\text { the experiment is completed (2023). } \\
\text { Sampling depth-0-20 cm. }\end{array}$ & ISO 10390:2005 \\
\hline Mobile potassium $\left(\mathrm{K}_{2} \mathrm{O}\right)$ & $\begin{array}{l}\text { By Egner-Riehm-Domingo } \\
\text { (A-L) method in a buffer } \\
\text { solution (pH 3.7) extraction } \\
\text { (lame emission spectrometer) }\end{array}$ & & {$[67]$} \\
\hline $\begin{array}{l}\text { Mineral nitrogen }\left(\mathrm{N}_{\min }\right) \\
\quad\left(\mathrm{N}-\mathrm{NO}_{3}+\mathrm{N}-\mathrm{NH}_{4}\right)\end{array}$ & $\begin{array}{c}\text { Determined in air-dry } \\
\text { samples, } 1 \mathrm{M} \mathrm{KCl} \text { extraction, } \\
\text { by flow analysis }\end{array}$ & $\begin{array}{l}\text { Samples }\left(\mathrm{N}_{\min } \text { and } \mathrm{S}_{\min }\right) \text { are taken } \\
\text { every spring after the regeneration of }\end{array}$ & ISO 14256-2:2005 \\
\hline $\begin{array}{l}\text { Mineral sulphur }\left(\mathrm{S}_{\min }\right) \\
\qquad\left(\mathrm{S}^{\left.-\mathrm{SO}_{4}\right)}\right.\end{array}$ & $\begin{array}{l}\text { Determined in } 1 \mathrm{M} \mathrm{KCl} \\
\text { extraction by turbidimetric } \\
\text { method AOAC-OM- } 973.57\end{array}$ & $\begin{array}{l}\text { plant vegetation before fertilization } \\
\text { with mineral fertilizers. Sampling } \\
\text { depth } 0-30 \text { and } 30-60 \mathrm{~cm} \text {. }\end{array}$ & [68] \\
\hline
\end{tabular}

The determination of soil $\mathrm{pH}$ was performed using 1:5 (vol/vol) soil suspension in $1 \mathrm{M} \mathrm{KCl}$. The mixture was shaken for $60 \mathrm{~min}$ and left to sit for $1 \mathrm{~h}$. The $\mathrm{pH}$ of the suspension was measured at $20 \pm 2{ }^{\circ} \mathrm{C}$ stirring with a $\mathrm{pH}$-meter.

Soil mobile phosphorus $\mathrm{P}_{2} \mathrm{O}_{5}$ and mobile potassium $\mathrm{K}_{2} \mathrm{O}$ were extracted using 1:20 (wt/vol) soil suspension of ammonium lactate-acetic acid extractant ( $\mathrm{pH}$ 3.7). The suspension was shaken for $4 \mathrm{~h}$. Mobile $\mathrm{P}_{2} \mathrm{O}_{5}$ was determined in extract using ammonium molybdate via the spectrometric method with a Shimadzu UV 1800 spectrophotometer. Mobile $\mathrm{K}_{2} \mathrm{O}$ was determined using flame emission spectroscopy with a JENWAY PFP7 flame photometer.

Mineral nitrogen $\left(\mathrm{N}_{\min }\right)$ was extracted in 1:5 (wt/vol) soil suspension of $1 \mathrm{M} \mathrm{KCl}$ solution. The suspension was shaken for $60 \mathrm{~min}$ at $20 \pm 2{ }^{\circ} \mathrm{C}$. After shaking, the suspension was filtrated and analyzed using a flow injection analysis (FIA) system by an FIASTAR 5000 analyzer. $\mathrm{N}_{\min }$ was calculated by adding the sum of nitrate and nitrite nitrogen with ammonia nitrogen.

Mineral sulphur $\left(\mathrm{SO}_{4}-\mathrm{S}\right)$ was extracted in a suspension of $1 \mathrm{M} \mathrm{KCl}$ solution. The suspension was shaken for $25 \mathrm{~min}$ at $20 \pm 2{ }^{\circ} \mathrm{C}$. After shaking, the suspension was filtrated, then precipitated with $\mathrm{BaCl}_{2}$ solution and analyzed using a spectrophotometer Shimadzu UV 1800.

\subsection{Plant Yield Evaluation}

The barley grain yield was determined from each plot by weighing it at harvest. Before barley was harvested, samples were taken by cutting the bottom parts of plants from 4-5 places in each plot separately. The weight of 1000-grain and grain-straw ratio were determined from the cuttings. The straw yield was calculated according to the determined ratio.

\subsection{Meteorological Conditions}

The meteorological conditions are described on the basis of the data recorded at the station of Lithuanian Hydrometeorological Service under the Ministry of Environment in Traku Vokè. The daily air temperature during the study period (April September) in 
2019 was $9.0-21.1{ }^{\circ} \mathrm{C}$. In 2020 (April September), it was 6.6-19.4 ${ }^{\circ} \mathrm{C}$. The average precipitation during the study period (April September) in 2019 was 1-100 mm. In 2020 (April September), it was 6-78 $\mathrm{mm}$.

The average precipitation and daily air temperature during the study period are presented in Table 5.

Table 5. Average precipitation and daily air temperature during the study period.

\begin{tabular}{ccccccc}
\hline & \multicolumn{7}{c}{$\mathbf{2 0 1 9}$} \\
\cline { 2 - 7 } & April & May & June & July & August & September \\
\hline $\begin{array}{c}\text { Precipitation, mm } \\
\begin{array}{c}\text { Daily air temperature } \\
\text { average, }{ }^{\circ} \mathrm{C}\end{array}\end{array}$ & 1 & 29 & 28 & 50 & 100 & 47 \\
\hline & 9.0 & 13.3 & 21.1 & 17.1 & 17.5 & 12.6 \\
\cline { 2 - 7 } & April & May & June & July & August & September \\
\hline $\begin{array}{c}\text { Precipitation, mm } \\
\text { Daily air temperature } \\
\text { average, }{ }^{\circ} \mathrm{C}\end{array}$ & 6 & 78 & 68 & 67 & 78 & 14 \\
\hline
\end{tabular}

Compared with the average perennial temperature, the 2019 average air temperature $\left(8.8^{\circ} \mathrm{C}\right)$ was $1.9^{\circ} \mathrm{C}$ higher than the average perennial air temperature (1981-2010 average), and the 2020 average air temperature $\left(9.2^{\circ} \mathrm{C}\right)$ was $2.3^{\circ} \mathrm{C}$ higher than the average perennial air temperature. Annual precipitation in 2020 in Lithuania was $646 \mathrm{~mm}(7 \%)$ less than the perennial norm $(694 \mathrm{~mm})$. Both years were very warm but lacked moisture, especially in 2019.

\subsection{Statistical Analysis}

Data analysis was performed using the computer program SPSS. The Duncan Multiple range Test using a 95\% $(p<0.05)$ probability level was used for the evaluation.

\section{Conclusions}

Since the soil under study is part of a long-term experiment that is still in progress, it is too early to draw some categorical conclusions. However, trends in the changes of microorganism community diversity can be predicted. As environmental conditions have been markedly sub-optimal, caution should be exercised in assessing the abundance of different physiological groups. Therefore, assessing the total abundance of microorganisms, it can be stated that the abundance of organotrophic and diazotrophic bacteria was highest during the summer period, while nitrifying bacteria and fungi were highest in the autumn. This can be attributed to the significant decrease in nitrogen in the soil in the spring of 2020 .

Comparing the research data with the control variants, we can state that the used different types of manure affect the abundance of most active soil microorganisms, but due to the standardization of the manure ration, it is not possible to provide a final answer.

The investigations of the mineral nitrogen in the soil in a stationary field experiment demonstrated that the concentration of mineral nitrogen depends not only on fertilization with organic fertilizers, but also on the meteorological conditions in the winter-spring period. The effectiveness of organic fertilizers compared to unfertilized plants became apparent only in the first year of the investigation after their application. The highest concentration of $\mathrm{N}_{\min }$ in the soil was determined by fertilizing the plants with the combination of $\mathrm{GPM}_{170}+\mathrm{A}$. The evaluation of the efficiency of the biological substances showed that the biological substance with the nitrogen-fixing bacteria Azotobacter spp. (No 1) tended to increase the $\mathrm{N}_{\min }$ concentration in the soil when used in combination with both GPM $\mathrm{M}_{170}$ and $\mathrm{GCM}_{170}$. 
The highest grain and straw yield were recorded in cases when the soil was fertilized with one mineral fertilizer and while adding mineral fertilizer rates to the granulated poultry manure.

Author Contributions: Methodology, A.K., E.B., A.M. and L.Z.; formal analysis, D.S. and A.M.; data curation, D.S., A.M. and E.B.; writing—original draft preparation, D.S.; writing—review and editing, A.K.; visualization, D.S. and supervision, A.K. All authors have read and agreed to the published version of the manuscript.

Funding: This research received no external funding.

Data Availability Statement: Data is contained within the article.

Conflicts of Interest: The authors declare no conflict of interest.

\section{References}

1. Merrill, S.D.; Liebig, A.; Tanaka, D.L.; Krupinsky, J.M.; Hanson, J.D. Comparison of soil quality and productivity at two sites differing in profile structure and topsoil properties. Agric. Ecosyst. Environ. 2013, 179, 53-61. [CrossRef]

2. Prosser, J.I. Dispersing misconceptions and identifying opportunities for the use of 'omics' in soil microbial ecology. Nat. Rev. Microbiol. 2015, 13, 439-446. [CrossRef]

3. Carini, P.; Marsden, P.J.; Leff, J.W.; Morgan, E.E.; Strickland, M.S.; Fierer, N. Relic DNA is abundant in soil and obscures estimates of soil microbial diversity. Nat. Microbiol. 2016, 19, 16242. [CrossRef]

4. Adetutu, E.M.; Ball, A.S.; Weber, J.; Aleer, S.; Dandie, C.E.; Juhasz, A.L. Impact of bacterial and fungal processes on 14Chexadecane mineralization in weathered hydrocarbon con-taminated soil. Sci. Total Environ. 2012, 414, 585-591. [CrossRef] [PubMed]

5. Savci, S. Investigation of Effect of Chemical Fertilizers on Environment. APCBEE Procedia 2012, 1, 287-292. [CrossRef]

6. Piotrowska-Długosz, A.; Wilczewski, E. Soil Phosphatase Activity and Phosphorus Content as Influenced by Catch Crops Cultivated as Green Manure. Pol. J. Environ. Stud. 2014, 23, 157-165.

7. Cao, H.; Chen, R.; Wang, L.; Jiang, L.; Yang, F.; Zheng, S.; Wang, G.; Lin, X. Soil pH, total phosphorus, climate and distance are the major factors influencing microbial activity at a regional spatial scale. Sci. Rep. 2016, 6, 25815. [CrossRef] [PubMed]

8. Jacoby, R.; Peukert, M.; Succurro, A.; Koprivova, A.; Kopriva, S. The Role of Soil Microorganisms in Plant Mineral NutritionCurrent Knowledge and Future Directions. Front. Plant Sci. 2017, 8, 1617. [CrossRef]

9. Qu, Y.; Tang, J.; Li, Z.; Zhou, Z.; Wang, J.; Wang, S.; Cao, Y. Soil Enzyme Activity and Microbial Metabolic Function Diversity in Soda Saline-Alkali Rice Paddy Fields of Northeast China. Sustainability 2020, 12, 10095. [CrossRef]

10. Sun, J.; Zhang, Q.; Zhou, J.; Wei, Q. Pyrosequencing technology reveals the impact of different manure doses on the bacterial community in apple rhizosphere soil. Appl. Soil Ecol. 2014, 78, 28-36. [CrossRef]

11. Daquiado, A.R.; Kappusamy, S.; Kim, A.Y.; Kim, J.H.; Yoon, Y.; Kim, P.J.; Oh, S.; Kwak, Y.; Lee, Y.B. Pyrosequencing analysis of bacterial community diversity in long-term fertilized paddy field soil. Appl. Soil Ecol. 2016, 108, 84-91. [CrossRef]

12. He, Z.; Pagiliari, P.H.; Waldrip, H.M. Applied and Environmental Chemistry of Animal Manure: A Review. Pedosphere 2016, 26, 779-816. [CrossRef]

13. Triberti, L.; Nastri, A.; Balcony, G. Long-term effects of crop rotation, manure and mineral fertilization on carbon sequestration and soil fertility. Eur. J. Agron. 2016, 74, 47-55. [CrossRef]

14. Zebarth, B.J.; Chabot, R.; Coulombe, J.; Simard, R.R.; Doheret, J.; Tremblay, N. Pelletized organo-mineral fertilizer product as a nitrogen source for potato production. Can. J. Soil Sci. 2005, 85, 387-395. [CrossRef]

15. Saidu, N.E.B.; Valente, S.; Bana, E.; Kirsch, G.; Bagrel, D.; Montenarh, M. Coumarin polysulfides inhibit cell growth and induce apoptosis in HCT116 colon cancer cells. Bioorg. Med. Chem. 2012, 20, 1584-1593. [CrossRef] [PubMed]

16. Mažeika, R.; Staugaitis, G.; Baltrušaitis, J. Engineered Pelletized Organo-Mineral Fertilizers (OMF) from Poultry Manure, Diammonium Phosphate and Potassium Chloride. ACS Sustain. Chem. Eng. 2016, 4, 2279-2285. [CrossRef]

17. Crusciol, C.A.C.; de Campos, M.; Martello, J.M.; Alves, C.S.; Nascimento, C.A.C.; dos Reis Pereira, J.C.; Cantarella, H. Organomineral Fertilizer as Source of $\mathrm{P}$ and $\mathrm{K}$ for Sugarcane. Sci. Rep. 2020, 10, 5398. [CrossRef]

18. Ye, C.; Huang, S.; Sha, C.; Wu, J.; Cui, C.; Su, J.; Ruan, J.; Tan, J.; Tang, H.; Xue, J. Changes of bacterial community in arable soil after short-term application of fresh manures and organic fertilizer. Environ. Techol. 2020, 20, 1-11. [CrossRef] [PubMed]

19. Šarauskas, E.; Naujokiene, V.; Lekavičienè, K.; Kriaučiūnienè, Z.; Jotautienè, E.; Jasinskas, A.; Zinkevičienè, R. Application of Granular and Non-Granular Organic Fertilizers in Terms of Energy, Environmental and Economic Efficiency. Sustainability 2021, 13, 9740. [CrossRef]

20. Kominko, H.; Gorazda, K.; Wzorek, Z. The Possibility of Organo-Mineral Fertilizer Production from Sewage Sludge. Waste Biomass Valoriz. 2017, 8, 1781-1791. [CrossRef]

21. Piaulokaitè-Motuzienè, L.; Končius, D.; Lapinskas, E. The occurrence of microorganisms as affected by different soil agrochemical properties. Agric. Sci. Art. 2005, 89, 154-162. (In Lithuanian) 
22. Kazlauskaitè-Jadzevičè, A.; Marcinkonis, S. Assessment of plant biomass carbon stock in differently renaturalized arable land. Žem. Moksl. 2015, 22, 121-132. (In Lithuanian)

23. Castaneda, L.E.; Barbosa, O. Metagenomic analysis exploring taxonomic and functional diversity of soil microbial communities in Chilean vineyards and surrounding native forests. PeerJ 2017, 5, e3098. [CrossRef] [PubMed]

24. Espinoza, L.; Norman, R.; Slaton, N.; Daniels, M. The nitrogen and phosphorous cycle in soils. Agric. Nat. Res. 2013, 2148, 1-4.

25. Žičkienè, L.; Staugaitis, G.; Mažvila, J.; Masevičienè, A.; Narutytè, I. Mineral nitrogen content fluxes in different texture soils on a rolling to hilly landscape. Žem. Moksl. 2015, 22, 198-208. (In Lithuanian)

26. Goloran, J.B.; Chen, C.R.; Phillips, I.R. Forms of nitrogen alter plant phosphorus uptake and pathways in rehabilitated highly alkaline bauxite processing residue sand. Land Degrad. Develop. 2017, 28, 628-637. [CrossRef]

27. Smalstienè, V.; Pranckietienè, I.; Dromantienè, R.; Šidlauskas, G. The influence of different nitrogen forms and application time on winter wheat. Žem. Mok. 2017, 24, 81-90. (In Lithuanian) [CrossRef]

28. Smith, W.N.; Grant, B.B.; Desjardins, R.L.; Kroebel, R.; Li, C.; Qian, B.; Worth, D.E.; McConkey, B.G.; Drury, C.F. Assessing the effects of climate change on crop production and GHG emissions in Canada. Agric. Ecosyst. Environ. 2013, 179, 139-150. [CrossRef]

29. Wang, J.; Wang, D.; Zhang, G.; Wang, Y.; Wang, C.; Teng, Y.; Christie, P. Nitrogen and phosphorus leaching losses from intensively managed paddy fields with straw retention. Agric. Water Manag. 2014, 141, 66-73. [CrossRef]

30. Adomaitis, T.; Mažvila, J.; Vaišvila, Z.; Arbačiauskas, J.; Antanaitis, A.; Lubytè, J.; Šumskis, D. Ilgalaikio tręšimo ịtaka anijonu išplovimui. Agriculture 2010, 97, 71-82. (In Lithuanian)

31. Masclaux-Daubresse, C.; Daniel-Vedele, F.; Dechorgnat, J.; Chardon, F.; Gau Chon, L.; Suzuki, A. Nitrogen uptake, assimilation and remobilization in plants: Challenges for sustainable and productive agriculture. Ann. Bot. 2010, 105, 1141-1157. [CrossRef] [PubMed]

32. EUR-Lex. The Nitrates Directive (91/676/EEC). 1991. Available online: https:/ / eur-lex.europa.eu/legal-content/EN/TXT/ PDF/?uri=CELEX:31991L0676\&from=EN (accessed on 24 November 2021).

33. Kirk, J.L.; Beaudette, L.A.; Hart, M.; Moutoglis, P.; Klironomos, J.N.; Lee, H.; Trevors, J.T. Methods of studying soil microbial diversity. J. Microbiol. Methods 2004, 58, 169-188. [CrossRef] [PubMed]

34. Jannson, J.K.; Hofmockel, K.S. The soil microbiome-From metagenomics to metaphenomics. Curr. Opin. Microbiol. 2018, 43, 162-168. [CrossRef]

35. Bučiene, A. On the sustainability of conventional, organic and integrated farming systems. Ecosyst. Health Sustain. Agric. 2012, 1, $42-50$.

36. Grzyb, A.; Wolna-Maruwka, A.; Niewiadomska, A. Environmental factors affecting the mineralization of crop residues. Agronomy 2020, 10, 1951. [CrossRef]

37. Grzyb, A.; Wolna-Maruwka, A.; Niewiadomska, A. The Significance of Microbial Transformation of Nitrogen Compounds in the Light of Integrated Crop Management. Agronomy 2021, 11, 1415. [CrossRef]

38. Gautam, A.; Sekaran, U.; Guzman, J.; Kovács, P.; Hernandez, J.L.G.; Kumar, S. Responses of soil microbial community structure and enzymatic activities to long-term application of mineral fertilizer and beef manure. Environ. Sustain. Indic. 2020, 8, 100073. [CrossRef]

39. Gans, J.; Wolinsky, M.; Dunbar, J.M. Computational improvements reveal great bacterial diversity and high metal toxicity in soil. Science 2005, 309, 1387-1390. [CrossRef] [PubMed]

40. Furtak, K.; Gajda, A.M. Activity and Variety of Soil Microorganisms Depending on the Diversity of the Soil Tillage System. In Sustainability of Agroecosystems; Intech Open: London, UK, 2018; pp. 45-61.

41. Bakšienè, E.; Ražukas, A.; Repečkienè, J.; Titova, J. Influence of different farming systems on the stability of low productivity soil in Southeast Lithuania. Zemdirb.-Agric. 2014, 101, 115-124. [CrossRef]

42. Piaulokaitè-Motuzienè, L.; Kočius, D. Nitrogen compounds transforming microorganisms succession assessment. Žem. Moksl. 2006, 4, 38-45. (In Lithuanian)

43. Francioli, D.; Schulz, E.; Lentendu, G.; Wubet, T.; Buscot, F.; Reitz, T. Mineral vs. Organic Amendments: Microbial Community Structure, Activity and Abundance of Agriculturally Relevant Microbes Are Driven by Long-Term Fertilization Strategies. Front. Microbiol. 2016, 7, 1446. [CrossRef] [PubMed]

44. Wu, J.; Sha, C.; Wang, M.; Ye, C.; Li, P.; Huang, S. Effect of Organic Fertilizer on Soil Bacteria in Maize Fields. Land 2021, 10, 328. [CrossRef]

45. Chen, Y.; Xin, L.; Liu, J.; Yuan, M.; Liu, S.; Jiang, W.; Chen, J. Changes in bacterial community of soil induced by long-term straw returning. Sci. Agric. 2016, 74, 349-356. [CrossRef]

46. Kyllmar, K.; Carlsson, C.; Gustafson, A.; Ulen, B.; Jahnsson, H. Nutrient discharge from small agricultural catchments in Sweden: Characteristics and trends. Agric. Ecosyst. Environ. 2006, 115, 15-26. [CrossRef]

47. Rutkowska, A.; Fotyma, M. Mineral Nitrogen as a Universal Soil Test to Predict Plant N Requirements and Ground Watter Pollution-Case Study for Poland; Intech Open: London, UK, 2011; pp. 333-350.

48. Žičkienè, L. Mineral Nitrogen Fluxes in Different Soils. Ph.D. Thesis, Lithuanian Research Centre for Agriculture and Forestry, Dotnuva, Lithuania, 2016; p. 138.

49. Plošek, L.; Elbl, J.; Lošák, T.; Kužel, S.; Kintl, A.; Juřička, D.; Kynický, J.; Martensson, A.; Brtnický, M. Leaching of mineral nitrogen in the soil influenced by addition of compost and N-mineral fertilizer. Acta Agric. Scand. 2017, 67, 607-614. [CrossRef] 
50. Yang, S.; Wang, Y.; Liu, R.; Zhang, A.; Yang, Z. Effect of Nitrate Leaching Caused by Swine Manure Application in Fields of the Yellow River Irrigation Zone of Ningxia, China. Sci. Rep. 2017, 7, 13693. [CrossRef] [PubMed]

51. Elbl, J.; Šimečkova, J.; Škarpa, P.; Kintl, A.; Brtnicky, M.; Vaverkova, M.D. Comparison of the Agricultural Use of Products from OrganicWaste Processing with Conventional Mineral Fertilizer: Potential Effects on Mineral Nitrogen Leaching and Soil Quality. Agronomy 2020, 10, 226. [CrossRef]

52. Liu, Z.; He, T.; Cao, T.; Yang, T.; Meng, J.; Chen, W. Effects of biochar application on nitrogen leaching, ammonia volatilization and nitrogen use efficiency in two distinct soils. J. Soil Sci. Plant Nutr. 2017, 17, 515-528. [CrossRef]

53. Schlegel, A.J.; Assefa, Y.; Bond, H.D.; Haag, L.A.; Stone, L.R. Changes in soil nutrients after 10 years of cattle manure and swine effluent application. Soil Tillage Res. 2017, 172, 48-58. [CrossRef]

54. Mažeika, R.; Arbačiauskas, J.; Masevičienè, A.; Narutytè, I.; Šumskis, D.; Žičkienè, L.; Rainys, K.; Drapanauskaite, D.; Staugaitis, G.; Baltrusaitis, J. Nutrient Dynamics and Plant Response in Soil to Organic Chicken Manure Based Fertilizers. Waste Biomass Valoriz. 2021, 12, 371-382. [CrossRef]

55. Ojo, J.A.; Olowoake, A.A.; Obembe, A. Efficacy of organomineral fertilizer and un-amended compost on the growth and yield of watermelon (Citrullus lanatus Thumb) in Ilorin Southern Guinea Savanna zone of Nigeria. Int. J. Recycl. Org. Waste Agric. 2014, 3, 121-125. [CrossRef]

56. Corrêa, J.C.; Grohskopf, M.A.; Nicoloso, R.D.S.; Lourenço, K.S.; Martini, R. Organic, organomineral, and mineral fertilizers with urease and nitrification inhibitors for wheat and corn under notillage. Pesqui. Agropecu. Bras. 2016, 51, 916-924. [CrossRef]

57. Davet, P.; Rouxel, F. Detection and Isolation of Soil Fungi; Science Publisher: Hauppauge, NY, USA, 2000.

58. Kuster, E. Outline of a comparative study of criteria used in characterization of the actinomycetes. J. Syst. Evol. Microbiol. 1959, 9, 98-104. [CrossRef]

59. Aquilanti, L.; Favilli, F.; Clemeti, F. Comparison of different strategies for isolation and preliminary identification of Azotobacter from soil samples. Soil Biol. Biochem. 2004, 36, 1475-1483. [CrossRef]

60. Carter, M.R.; Gregorich, E.G. Soil Sampling and Methods of Analysis; CRC Press: Boca Raton, FL, USA, 2007 ; p. 1224.

61. Nelson, P.E.; Toussoun, T.A.; Marasas, W.F.O. Fusarium Species: An Illustrated Manual for Identification; Penn State University Press: University Park, PA, USA, 1990; p. 206.

62. Watanabe, T. Pictorial Atlas of Soil and Seed Fungi/Morphologies of Cultured Fungi and Key to Species; CRC Press: Boca Raton, FL, USA, 2002.

63. Domsch, K.H.; Gams, W.; Anderson, T.H. Compendium of Soil Fungi; IHW-Verlag: Eching, Germany, $2007 ;$ p. 672.

64. Samson, R.A.; Visagie, C.M.; Houbraken, J.; Hong, S.B.; Hubka, V.; Klaassen, C.H.W.; Perrone, G.; Seifert, K.A.; Susca, A.; Tanney, J.B.; et al. Phylogeny, identification and nomenclature of the genus Aspergillus. Stud. Mycol. 2014, 78, 141-173. [CrossRef]

65. Visagie, C.M.; Houbraken, J.; Frisvad, J.C.; Hong, S.B.; Klaassen, C.H.W.; Perrone, G.; Seifert, K.A.; Varga, J.; Yaguchi, T.; Samsom, R.A. Identification and nomenclature of the genus Penicillium. Stud. Mycol. 2014, 78, 343-371. [CrossRef]

66. Salina, O. Micromycetes of Trichoderma sect. Longibrachiatum in Lithuania. Bot. Lith. 2007, 13, 261-269.

67. Egnér, H.; Riehm, H.; Domingo, W.R. Investigations on soil chemical analysis as a basis of the evaluation of plant nutrient status of soils II. Chemical extraction methods for phosphorus and potassium determination. Lantbrukshögsk. Ann. 1960, 26, $199-215$.

68. Association of Analytical Chemists International (AOAC). AOAC Official Method 973.57 Sulfate in Water. Turbidimetric Method; Scientific Research: Atlanta, GA, USA, 2000; pp. 23-24. 